\title{
Beet (Beta vulgaris) Improve Blood Glucose and AKT2 Gene Expression in High Fat and Fructose-induced Rats
}

\author{
M. Windi Dona Fitri , Arta Farmawati D, Sunarti Sunarti*iD \\ Department of Biochemistry, Faculty of Medicine, Public Health and Nursing, Universitas Gadjah Mada, Yogyakarta, Indonesia
}

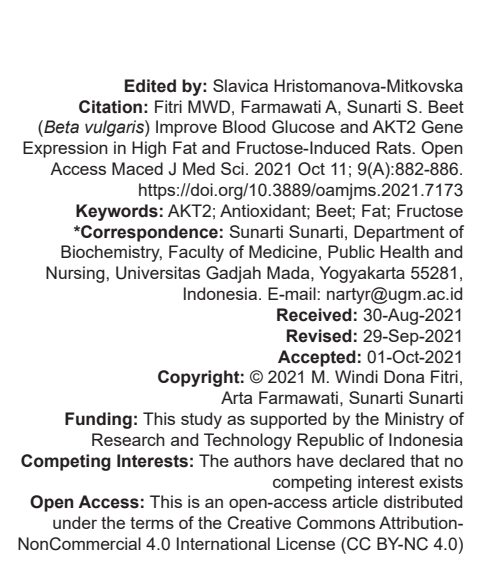

\begin{abstract}
BACKGROUND: Diet components significant effects on glucose homeostasis. A diet contains high saturated fat and fructose induces insulin resistance and enhanced blood glucose. In contrast, food containing flavonoids such as beet can improve glucose homeostasis via modulation of gene expression, for example., AKT2, involving glucose metabolism.

AIM: This study was to evaluate the benefit of beet on AKT2 gene expression and fasting glucose (FG).

METHODS: Twenty Wistar male was divided into five groups: Normal were fed a normal diet, group HFFD was given a diet containing high fat and fructose, and three groups (HFB1, HFB2, HFB3) were given a diet containing high fat and fructose for 8 weeks and continuous fed beet-contained normal diet for 6 weeks. The percentage of beet in the diet for each $6 \%, 9 \%$, and $12 \%$, respectively.

RESULTS: The FG was measured before and after the intervention, whereas the gene expression of AKT2 at skeletal muscle tissue was determined after the intervention. A diet high in fat and fructose increased FG levels, and
\end{abstract} a beet-contained diet decreased it.

CONCLUSIONS: The beet $9 \%$ substituted diet can improve glucose homeostasis from the effects of a high fat and fructose diet, and the expression of the AKT2 gene may have a role in the process.

\section{Introduction}

The composition of the diet has significant and clinically relevant effects on circulating glucose, and it is influenced by food components, such as form, kind, and amount. High saturated fat and high fructose have been known can induce insulin resistance in tissues and enhanced blood glucose. The rats fed a diet containing high fat or high fat and also a high fructose diet had fasting blood glucose (FBG) concentration higher than those in the rats control diet [1]. On the other hand, a high polyphenol diet can influence gene expression involved in insulin signaling, insulin secretion, and hepatic gluconeogenesis pathways. Many polyphenols were reported to influencing the expression of insulin receptors substrate 1 (IRS1), serine/threonineprotein kinase 1 (AKT1), and phosphoenolpyruvate carboxykinase in human hepatic cells (HEPG2) [2]. In addition, various polyphenols have been shown antioxidant properties that have biological effects through the starting responses of cell signaling and interplay with both extracellular and intracellular receptors. The interaction between polyphenol and cell membrane can induce changing of membrane function, for example., stimulation of signal transduction [3].
Beetroot (Beta vulgaris L.) contains a lot of phenolic substances and others, for example., betalains, that can improve health [4]. Beetroot has antioxidative properties and hepatoprotective activity [5], and some studies showed that beetroot or products from its derivative can glycemia control [6]. Lorizola et al. [7] reported that supplementation beet stalks and leaves containing flavonoids could ameliorate glucose homeostasis significantly in the high-fat diet-fed mice. An ethyl acetate fraction of Molineria latifolia containing high polyphenol can be reported to escalate the effectors' expression of insulin signaling such as GLUT4, hexokinase 2, IRS1, IRS2, and AKT2 via phosphorylation of IRS1/ Akt pathway in tissues of skeletal muscle of high-fat diet-induced diabetic male rats [3]. AKT2, a serine/ threonine kinase, has a critical role in transduce insulin stimulation into metabolic responses in target tissues, including skeletal muscle, liver, and adipose tissue [8]. In mice and humans, loss of function mutations in AKT2, specifically in skeletal muscle, were reported to relating glucose intolerant and insulin resistance because the most postprandial glucose is used by the skeletal muscle [9]. At the transcript level, the AKT2 regulates the expression of the GLUT1 gene to modulate the availability of glucose and abrogating the expression of AKT2 impaired glucose uptake by the cell. It showed 
that the AKT2 has an important role in a pathway that directly integrates glucose, GLUT1 expression, and glucose availability to maintain the viability of AKT2dependent cells [10].

\section{Methods}

\section{Animals and experimental studies}

Approvement of the present research was obtained from the Ethical Committee of Integrated Research and Testing Laboratory, Universitas Gadjah Mada (Approval number: 00011/04/LPPT/V/2019). Wistar male rats at the age of 1 month $(n=20)$, weighing $\pm 150 \mathrm{~g}$, were obtained from Pharmacy Faculty, Universitas Gadjah Mada. Each rat was kept in cages in a room with a temperature of $25^{\circ} \mathrm{C}$ and the cycle of light/dark12:12 h. The rats were acclimated for seven days using AIN93M formulation and water ad libitum and then were randomly assigned to five groups consisted of four rats for each group. Group N was fed a normal diet, group HFFD was fed a diet containing high fat and high fructose, and three groups (HFB1, HFB2, and HFB3) were fed a diet containing high fat and high fructose for eight weeks and continuously fed a beetcontained normal diet for 6 weeks. The substitution percentage of beet in the diet for each $6 \%, 9 \%$, and $12 \%$, respectively. All rats were given distilled water ad libitum during the study. The formulation of the diet showed in Table 1.

Table 1: Diet composition

\begin{tabular}{|c|c|c|c|c|c|}
\hline Substance (g/kg diet) & $\begin{array}{l}\text { Standard } \\
\operatorname{diet}(\mathrm{N})\end{array}$ & $\begin{array}{l}\text { High fat and } \\
\text { fructose diet } \\
\text { (HFFD) }\end{array}$ & $\begin{array}{l}\text { Intervention } \\
\text { diet with } \\
6 \% \text { beet }\end{array}$ & $\begin{array}{l}\text { Intervention } \\
\text { diet with } \\
9 \% \text { beet }\end{array}$ & $\begin{array}{l}\text { Intervention } \\
\text { diet with } \\
12 \% \text { beet }\end{array}$ \\
\hline Cornstarch & 621 & 300 & 561 & 531 & 501 \\
\hline Casein & 140 & 140 & 140 & 140 & 140 \\
\hline Sucrose & 100 & - & 100 & 100 & 100 \\
\hline Trans fat & - & 214 & - & - & - \\
\hline Fructose & - & 250 & - & - & - \\
\hline Bit & - & - & 60 & 90 & 120 \\
\hline Alfa cell (Fiber) & 50 & 50 & 50 & 50 & 50 \\
\hline $\begin{array}{l}\text { Mineral mix } \\
(\text { AIN'93M-MX) }\end{array}$ & 35 & 35 & 35 & 35 & 35 \\
\hline $\begin{array}{l}\text { Vitamin mix } \\
\text { (AIN'93-VX) }\end{array}$ & 10 & 10 & 10 & 10 & 10 \\
\hline Methoinine & 1.8 & 1.8 & 1.8 & 1.8 & 1.8 \\
\hline Choline chloride & 2.5 & 2.5 & 2.5 & 2.5 & 2.5 \\
\hline Tert-butylhydroquinone & 0.008 & 0.008 & 0.008 & 0.008 & 0.008 \\
\hline
\end{tabular}

\section{Laboratory analyses}

The levels of fasting glucose (FG) were measured before and after the intervention, whereas the gene expression of AKT2 at skeletal muscle tissue was determined after the intervention. The serum obtained from fasting (8-10 h without diet) whole blood that taken from sinus orbitalis, enter the tube and stay for $2 \mathrm{~h}$ at room temperature, and then centrifuged at $3000 \mathrm{rpm}$ for $15 \mathrm{~min}$, the top layer solution is serum. The rats were anesthetized to get skeletal muscle tissue using intraperitoneal injection of ketamine and sacrificed. The levels of serum glucose were measured by the colorimetric method according to the protocol in glucose Diasys Kit. The steps of analysis of AKT2 gene expression using quantitative polymerase chain reaction (qPCR) are as follows: The total RNA of rats skeletal muscle was isolated with a TriRNA (Favorgen) based on instructions manufacturer. The RNA concentration was determined by Nanodrop, and the synthesis of cDNA using kit from Revertaid First Strand cDNA Synthesis Kit (Thermo scientific). The gene expression of AKT2 was analyzed using SSoAdvanced Universal SyBR Green Supermix (Biorad). Primer pairs are listed in Table 2. The qPCR protocol was as follows: Early denaturation for $5 \mathrm{~min}$ at temperature $95^{\circ} \mathrm{C}$, denaturation for $1 \mathrm{~min}$ at $95^{\circ} \mathrm{C}$, annealing for $1 \mathrm{~min}$ at $58^{\circ} \mathrm{C}$ and elongation for $1 \mathrm{~min} 72^{\circ} \mathrm{C}$ with 40 cycles. The primary sequences of AKT2 and $\beta$-actin (purchased from Genetica Science) were listed in Table 2.

Table 2: Primers of reverse transcription PCR analysis

\begin{tabular}{lll}
\hline Gene & Primer sequence & Product \\
\hline AKT2 & F :5'GGAGGTCATGGAGCATCGGTTC3' & $80 \mathrm{bp}$ \\
& $\mathrm{R}:$ 5'GTTTGAAGGGTGGCAGGAGC3' $^{\prime}$ & \\
Beta actin & F : 5'TGTGGATTGGTGGCTTATC3' & $149 \mathrm{bp}$ \\
& R : 5'AGAAAGGGTGTAAAACGCAG3' & \\
\hline
\end{tabular}

\section{Statistical analysis}

The results are presented as mean \pm standard deviation. The FBG and AKT2 gene expression were determined by one-way ANOVA and next to a post hoc multiple comparison test. Comparative analysis of pretest-posttest data using paired sample t-test.

\section{Results}

Changes in the levels of blood glucose of fasting rats after received a diet high in fat and fructose (before rats get a beet-contained diet) and after given a beet-contained diet were presented in Table 3. The HFFD, HFB1, HFB2, and HFB3 groups had FBG levels significantly higher than those in the $\mathrm{N}$ groups $(p<0.05)$. The beet $9 \%$-contained diet can significantly reduce the $\mathrm{FBG}$ levels.

Table 3: The mean of the levels of blood glucose of fasting rats after induction and after intervention

\begin{tabular}{llllll}
\hline Groups & $\mathrm{N}$ & \multicolumn{2}{l}{ Average of FBG levels $(\mathrm{mg} / \mathrm{dL})$} & $\Delta \mathrm{FBG}$ & \multirow{2}{*}{$\mathrm{P}^{* *}$} \\
\cline { 3 - 4 } & & \multicolumn{1}{c}{ After induction HFFD } & After beet intervention & & \\
\hline $\mathrm{N}$ & 4 & $109.00 \pm 8.52^{\mathrm{a}}$ & $107.88 \pm 12.24^{\mathrm{a}}$ & -1.13 & 0.824 \\
$\mathrm{HFFD}$ & 4 & $132.25 \pm 13.60^{\mathrm{b}}$ & $131 \pm 10.03^{\mathrm{b}}$ & -1.25 & 0.825 \\
$\mathrm{HFB1}$ & 4 & $129.5 \pm 6.24^{\mathrm{b}}$ & $117 \pm 8.29^{\mathrm{ab}}$ & -12.50 & 0.112 \\
$\mathrm{HFB2}$ & 4 & $133 \pm 8.29^{\mathrm{b}}$ & $104.33 \pm 5.44^{\mathrm{a}}$ & -28.68 & $0.017^{\#}$ \\
HFB3 & 4 & $131.25 \pm 4.03^{\mathrm{b}}$ & $127 \pm 3.74^{\mathrm{b}}$ & 4.25 & 0.294 \\
$\mathrm{P}^{*}$ & & $0.007^{*}$ & $0.002^{\#}$ & & \\
\hline
\end{tabular}

$\mathrm{N}$ : Normal control group; HFFD: Rats received high fat and fructose; HFB1: HFFD was given by beet $6 \%$-contained diet; HFB2: HFFD fed by beet $9 \%$-contained diet; HFB3: HFFD get beet $12 \%$-contained diet. Data are prebsented in mean \pm standard deviation. Superscript a and $b: P<0.05$ according to One Way ANOVA and Tukey test; Superscript ab: There is no difference in either $a$ or $b$; $P^{*}$ : Difference of FBG levels between groups; $\mathrm{P}^{* *}$ : Difference of FBG levels before and after beet intervention at same groups; Sign \# shows that significant. FBG: Fasting blood glucose.

There was no significant correction between the expression of the AKT2 gene and the FG because 


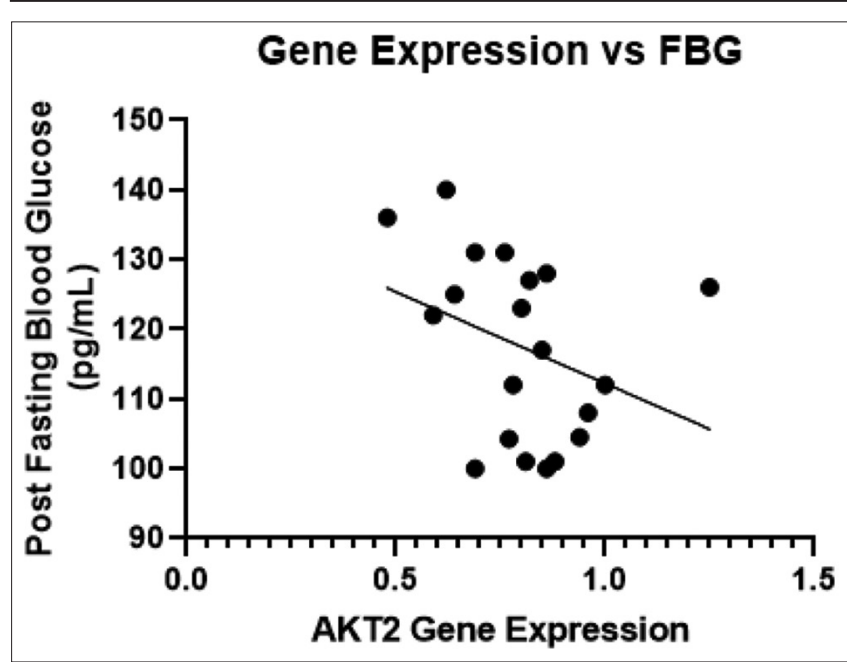

Figure 1: The correlation between the expression of AKT2 gene and post fasting blood glucose

glucose metabolism involved many pathways, such as the previous study (Figure 1). This study showed that the effect of beet on AKT2 gene expression was not significant, although the AKT2 gene expression in the HFFD group was lowest, but the AKT2 gene expression in the HFB2 group closely to those in the $\mathrm{N}$ group (Figure 2).

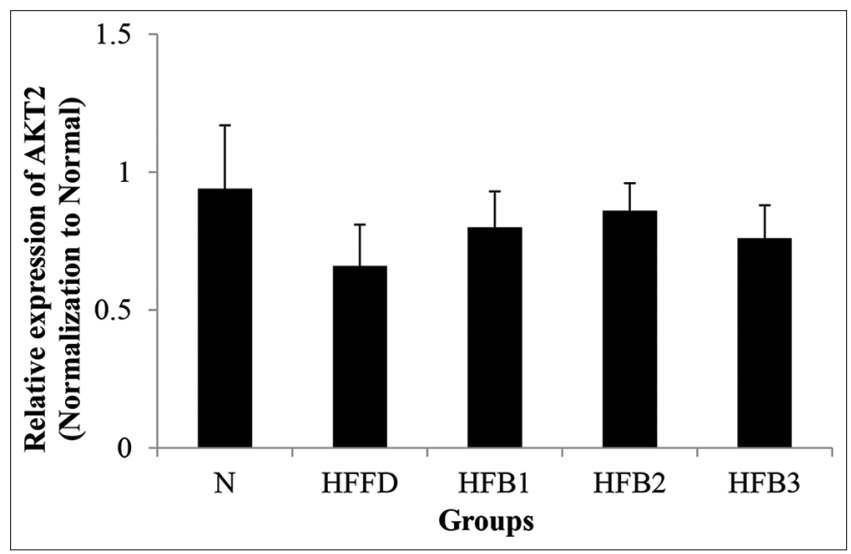

Figure 2: The expression of AKT2 gene (N: Normal control group; HFFD: Rats received high fat and fructose; HFB1: HFFD was given by beet 6\%-contained diet; HFB2: HFFD fed by beet $9 \%$-contained diet; HFB3: HFFD get beet 12\%-contained diet)

\section{Discussion}

This present study showed that the rats in HFFD, HFB1, HFB2, and HFB3 groups had FG between $130,135 \mathrm{~g} / \mathrm{dL}$, and it more than the normal group $(\mathrm{N})$. According to the previous studies that the levels of blood glucose of fasting rats fed a diet containing high fat and fructose for six weeks were higher than rats fed the standard diet [11]. Haroun et al. [12] also reported that rats fed a diet containing high fat only or fructose alone for 5 weeks had higher blood glucose levels than normal control rats. Another study showed that the combination of a highfat diet and high fructose beverages induced fasting hyperglycemia after 6 months [13]. In some studies, using animals showed that high-fat diet impaired glucose tolerance that was associated with decreased basal and insulin-stimulated glucose metabolism, whereas, in the human, a high-fat diet reduced insulin sensitivity. In this study, we used saturated fat, and saturated fat is more deleterious with respect to fatinduced insulin insensitivity than monounsaturated and polyunsaturated fat [14]. Insulin insensitivity or insulin resistance is also reported to be associated with high fructose consumption. Fructose induced-insulin resistance can be mediated by an increase of reactive oxygen species that mediates a proinflammatory cascade to lead to an increase of adipogenesis, release of inflammatory cytokines, and decrease in adiponectin cause insulin resistance [15], [16].

After getting a beet-contained diet, the FBG in HFB1, HFB2, and HFB groups decreased, especially in the HFB2 group that gets a beet $9 \%$ contained diet, seen significantly. It showed that beet $9 \%$ as a physiological dose having the best effects to maintain glucose homeostasis. The result of this present study, in accordance with the previous research by Lorizola et al. [17] reported the rats treated with the stem and leaf parts of beets had a decrease in blood glucose levels compared to the untreated rat group. The result of this study accordance with the study Gezginci-Oktayoglu that reported that extract of $B$. vulgaris $L$. var. cicla can increase GLUT2 via AKT2 and defence of antioxidant in the liver lead to improve hyperglycemia [18]. AKT is involved in the metabolism regulation of glucose and the pathway of intracellular insulin transduction and metabolism of energy in the liver [19].

The AKT2 was reported to modulate the availability of glucose through expression regulation of GLUT1 at the level of transcript and abrogating expression of AKT2 impaired glucose uptake by the cell [10]. In the present research, the effect of beetsubstituted diet on the gene expression of AKT between groups was not statistically significantly different, but the rats get beet substituted diet indicated AKT gene expression higher than those in the HFFD rat group, and its expression closely to normal rat group was beet $9 \%$ substituted diet (Figure 2). It suggested that substitution of beet $9 \%$ in the diet can meet the physiological need to improve the effects of a diet containing high fat and fructose related to glucose homeostasis. In low doses (beet 6\%) may allow less effect on ligands, whereas a higher dose (beet 12\%) over a long period of time may trigger prooxidant activity. Flavonoids given in high amounts can act as prooxidants. Fang et al. [20] reported that flavonoids become prooxidant activity occurs by triggering $\mathrm{OH}$ in the presence of $\mathrm{Cu}+$ and $\mathrm{H}_{2} \mathrm{O}_{2}$. In addition, the expression of the AKT2 gene has a negative correlation with FG, but it was not statically significant. It is because glucose metabolism involved many pathways. Although the skeletal muscle AKT2 has 
been believed to play an important role in homeostasis glucose, however, the mice's skeletal muscle only lacking AKT2 showed cannot stimulate insulin resistance or inhibit the uptake of glucose. It showed that besides skeletal muscle AKT2, another signaling molecule might be involved in perturbation tolerance of glucose and sensitivity of insulin in vivo [10].

\section{Conclusion}

The beet $9 \%$ substituted diet can improve glucose homeostasis from the effects of a diet containing high fat and fructose, and the expression of the AKT2 gene may have a role in the process.

\section{Acknowledgments}

We want to thank Abrory Agus Cahya Pramana, Dianandha Septiana Rubi, and Salma Nadiyah for their research assistant and discussion. This study was supported by The Ministry of Research and Technology Republic of Indonesia.

\section{References}

1. Huang BW, Chiang MT, Yao HT, Chiang W. The effect of high-fat and high-fructose diets on glucose tolerance and plasma lipid and leptin levels in rats. Diabetes Obes Metab. 2004;6(2):120-6. https://doi.org/10.1111/j.1462-8902.2004.00323.x

PMid: 14746577

2. Lin CL and Lin JK. Epigallocatechin gallate (EGCG) attenuates high glucose-induced insulin signaling blockade in human hepG2 hepatoma cells. Mol Nutr Food Res. 2008;52(8):930-9. https://doi.org/10.1002/mnfr.200700437

PMid: 18496818

3. Kang GG, Francis N, Hill R, Waters D, Blanchard C, Santhakumar AB. A review of dietary polyphenols and gene expression in molecular pathways associated with Type 2 diabetes mellitus. Int J Mol Sci. 2020;21(1):140. https://doi. org/10.3390/ijms21010140

PMid:31878222

4. Vidal PJ, López-Nicolás JM, Gandía-Herrero F, GarcíaCarmona F. Inactivation of lipoxygenase and cyclooxygenase by natural betalains and semi-synthetic analogues. Food Chem. 2014;154:246-54. https://doi.org/10.1016/j. foodchem.2014.01.014

PMid:24518339

5. Vulić JJ, Ćebović TN, Čanadanović-Brunet JM, Ćetković GS, Čanadanović VM, Djilas SM, et al. In vivo and in vitro antioxidant effects of beetroot pomace extracts. Journal of Funct Foods. 2014;6(1):168-75. https://doi.org/10.1016/j.jf.2013.10.003
6. Gilchrist M, Winyard PG, Fulford J, Anning C, Shore AC, Benjamin N. Dietary nitrate supplementation improves reaction time in Type 2 diabetes: Development and application of a novel nitrate depleted beetroot juice placebo. Nitric Oxide. 2014;40:67-74. https://doi.org/10.1016/j.niox.2014.05.003 PMid:24858657

7. Lorizola IM, Miyamoto JÉ, Vieira AL, Sumere BR, Bezerra RM, Torsoni MA, et al. Beet (Beta vulgaris L.) stalk and leaf supplementation improves glucose homeostasis and insulin resistance markers in liver of mice exposed to a high-fat diet. Res Sq. 2020;1-26. https://doi.org/10.21203/rs.3.rs-40368/v1

8. Minic M, Rocha N, Harris J, Groeneveld MP, Leiter S, Wareham N, et al. Constitutive activation of AKT2 in humans leads to hypoglycemia without fatty liver or metabolic dyslipidemia. J Clin Endocrinol Metab. 2017;102(8):2914-21. https://doi.org/10.1210/jc.2017-00768 PMid:28541532

9. Jaiswal N, Gavin MG, Quinn WJ, Luongo TS, Gelfer RG, Baur JA, et al. The role of skeletal muscle AKT in the regulation of muscle mass and glucose homeostasis. Mol Metab. 2019;28:113. https://doi.org/10.1016/j.molmet.2019.08.001 PMid:31444134

10. Jensen PJ, Gunter LB, Carayannopoulos MO. AKT2 modulates glucose availability and downstream apoptotic pathways during development. J Biol Chem. 2010;285(23):17673-680. https:// doi.org/10.1074/jbc.m109.079343

PMid:20356836

11. Chayati I, Sunarti, Marsono Y, Astuti M. Anthocyanin extract of purple corn improves hyperglycemia and insulin resistance of rats fed high fat and fructose diet via GLP1 and GLP1R mechanism. J Food Nutr Res. 2019;7(4):303-10. https://doi. org/10.12691/jfnr-7-4-7

12. Haroun MA, Elsayed LA, Rashed LA, Mohammed MA The effect of high fat diet and high fructose intake on insulin resistance and GLP-1 in experimental animals. Med J Cairo Univ. 2011;79(2):2332.

13. Lozano I, van der WR, Bietiger W, Seyfritz E, Peronet C Pinget $\mathrm{M}$, et al. High-fructose and high-fat diet-induced disorders in rats: Impact on diabetes risk, hepatic and vascular complications. Nutr Metab (Lond). 2016;13:15. https://doi. org/10.1186/s12986-016-0074-1

PMid:26918024

14. Lichtenstein $\mathrm{AH}$, Schwab US. Relationship of dietary fat to glucose metabolism. Atherosclerosis. 2000;150(2):227-43. https://doi.org/10.1016/s0021-9150(99)00504-3 PMid: 10856515

15. Khitan Z, Kim DH. Fructose: A key factor in the development of metabolic syndrome and hypertension. J Nutr Metab. 2013;2013:682673.

PMid:23762544

16. Ang BR, Yu GF. The role of fructose in Type 2 diabetes and other metabolic diseases. J Nutr Food Sci. 2018;8:14.

17. Lorizola IM, Furlan C, Portovedo M, Milanski M, Botelho PB, Bezerra R, et al. Beet stalks and leaves (Beta vulgaris L.) protect against high-fat diet-induced oxidative damage in the liver in mice. Nutrients. 2018;10(7):872. https://doi.org/10.3390/ nu10070872

PMid:29976910

18. Gezginci-Oktayoglu S, Sacan O, Bolkent S, Ipci Y, Kabasakal L, Sener G, et al. Chard (Beta vulgaris L. var. cicla) extract ameliorates hyperglycemia by increasing GLUT2 through AKT2 and antioxidant defense in the liver of rats. Acta Histochem. 2014;116(1):32-9. https://doi.org/10.1016/j.acthis.2013.04.016 PMid:23746671

19. Liu Y, Liang X, Zhang G, Kong L, Peng W, Zhang H. Galangin 
and pinocembrin from propolis ameliorate insulin resistance in HepG2 cells via regulating AKT/mTOR signaling. Evid Based Complement Alternat Med. 2018;2018:971842. https://doi. org/10.1155/2018/7971842

PMid:30420897
20. Fang X, Gao W, Yang Z, Gao Z, Li H. Dual anti/prooxidant behaviors of flavonoids pertained to $\mathrm{Cu}$ (II) catalyzed tyrosine nitration of insulin receptor kinase domain in the antidiabetic study. J Agric Food Chem. 2020;68(22):6202-11. https://doi. org/10.1021/acs.jafc.0c01676

PMid:32395994 